\title{
sciendo
}

DOI 10.2478/sbe-2020-0045

SBE no. 15(3) 2020

\section{THE CHALLENGES OF REFORMING THE INTERNATIONAL MONETARY SYSTEM IN THE POST COVID-19 WORLD}

\author{
MĂRGINEAN SILVIA CRISTINA \\ Lucian Blaga University of Sibiu, Romania \\ ORĂȘTEAN RAMONA \\ Lucian Blaga University of Sibiu, Romania
}

\begin{abstract}
:
The paper analyzes if the international monetary system calls for reform and whether China and the renminbi will play a decisive role in the post COVID-19 world. It also evaluates the main scenarios and trends that is being discussed since the global crisis - selecting the relevant authors, journals, institutions and opinions - examines present conditions and tries to extrapolate into future trends. Opting for a nontechnical approach, the article could be a good insight into the international monetary system, for academics, non-experts and policy makers. The paper concludes that if the 2008 crisis has induced the growth of the China role in the international monetary governance and the increase of the renminbi internationalization, the COVID-19 pandemic and post crisis reconstruction could generate a deeper reform of the international monetary system, in which the Chinese currency will strengthen its global position alongside the US dollar and the euro.
\end{abstract}

Key words: reform; multimonetary system; renminbi; US dollar; euro; post COVID-19.

\section{Introduction}

The weaknesses of the international monetary system and the need for reform were widely debated among economists and policy makers after the outbreak of the global crisis in 2008. They identified major deficiencies in the system: high volatility of exchange rates; persistent misalignments of exchanges rates and important macroeconomic imbalances; inadequate global adjustment mechanisms; failure of promoting economic cooperation between dominant economic areas; inability of preventing and management the financial crisis. The possible reforms focused on: management of international capital flows; reserve assets diversification; strengthening policy collaboration; rethinking financial market regulations and surveillance. Nevertheless, the international currency was in the spotlight and we had been following the discussions related to monetary dimension of the reform. 
The COVID-19 pandemic requires us to think more deeply in terms of reform. As a post crisis reconstruction, a new international monetary order could be established to face future challenges.

Reform initiatives are diverse, from the call for an increased flexibility of exchange rates and a reduction of reserve accumulations to expand the role of the renminbi and the SDR. These sparks some questions which puzzle the academic, economic and political communities.

The reform of the international monetary system in 1944 occurred as a response to unusual circumstances - the collapse of currency and commercial regimes in the 1930s and the World Wars. The first question is if now a reform on the same level as 1944 can be considered.

The second question is whether a new international monetary system can be conceived by reviving the Bretton Woods system. Today, same as before, the international monetary system has a center, with the exorbitant privilege of issuing reserve currency, and a periphery, with the right of using it. In the 1960s, the center was the US and the periphery included Europe and Japan. Now, a new periphery is shaping - emerging markets from Asia and Latin America - that makes the center position a subject of dispute between United States, China and Europe.

While the gold standard prevailed in the 19th century, considered to be necessary and enough for a country to become active on international financial markets, the third question is whether the adhesion to a metallic, gold-like standard is now viable.

We cannot exclude the keynesian model as well, with a global/supranational currency having the role of international currency, which leads to the fourth question - is a global currency system possible?

The fifth question is how long the post-Bretton Woods system will continue, with the US dollar as the dominant international currency, and when the renminbi could become a true rival of the US dollar?

Finally, the sixth question occurs, to what extent can the current international monetary system become a tripolar one - the US dollar, the euro and the renminbi - or even multipolar?

To answer these questions, the paper presents a collection of new insights and discusses some of the proposals for redesigning the international monetary system, focusing on currency component. The rest of the paper is organized as follows. Section 2 gives an overview and review of literature on different ways of organizing the international monetary system. Section 3 looks at the alternatives models of the current international monetary system. Section 4 concludes.

The paper analyzes if the international monetary system calls for reform and whether China and the renminbi will play a decisive role in the post COVID-19 world. It also evaluates the main scenarios and trends that is being discussed since the global crisis - selecting the relevant authors, journals, institutions and opinions - examines present conditions and tries to extrapolate into future trends. Opting for a nontechnical approach, the article could be a good insight into the international monetary system and the role of China, for academics, non-experts and policy makers. We conclude that if the 2008 crisis has induced the growth of the China role in the international monetary governance and the 
increase of the renminbi internationalization, the COVID-19 pandemic and post crisis reconstruction could generate a deeper reform of the international monetary system, in which the Chinese currency will strengthen its global position alongside the US dollar and the euro.

\section{Literature review}

The reform of the international monetary system became an important topic for academic and non-academic specialists after 2009. There are two groups of contributions: reports, studies and policy papers provided by international institutions and scientific articles. The interest was not linear over time and we noted a concentration of studies during 2011-2012 and after 2016. The idea has now returned during the COVID-19 pandemic crisis and the economic crisis that accompanies it.

The International Monetary Fund (IMF, 2009) proposed three alternatives to the current monetary system: a multiple-currency system with multiple reserve currencies, but without a dominant currency; an SDR-based system; a system with a global, BANCORtype currency that circulates along with national currencies. Their analysis is based on the following criteria: stability, efficiency, political feasibility, ease of implementation and fairness.

The Royal Institute of International Affairs from London (Subacchi \& Driffill, 2010) presented the following solutions in favor of a multipolar reserve system and for expanding the use of the SDR: by increasing the SDR supply in a frequent and predictable way and without political interference; through creation of an International Committee of Monetary Policy to make recommendations to the IMF for new SDR allocations; by creating a substitution account; by increasing the SDR demand and usage.

In the hypothesis that the floating of main currencies will continue and the capital accounts will gradually be liberalized, the World Bank (WB, 2011) anticipated three scenarios for configuring the monetary system: the US dollar keeps its position of dominant currency, at least until 2025, if the US will succeed in reducing unsustainable fiscal deficits and the China and the European Union will delay the reforms for expanding the international use of their currencies; a multicurrency system, assuming the US dollar will lose its dominant position before 2025 and will be replaced by a system with three currencies (US dollar, euro and renminbi) of equal values; a unique multilateral reserve currency (SDR or another composite currency) issued by a global central bank.

World Economic Forum (WEF, 2012) established a set of provocative scenarios for the international monetary system by the end of 2030: a reversion to regionalism, with a fragmented international monetary system into a multitude of regional systems; G2 rebalancing (United States and China), which would dominate the international monetary system and implies that the US dollar will remain the main invoicing currency while the renminbi will be the currency used in inter-Asian trade and in trade between Asia and other emerging countries, and the Eurozone will disintegrate; reconciling a two-speed world, with the renminbi as a regional currency in Asia, de facto as a BRICS ${ }^{`}$ countries currency, and a limited expansion of the euro, even if the Eurozone problems were to be solved. 
D'Arista (2009) described some of the reform proposals and concluded on three: an international commodity reserve currency; new issues of SDR; a reserve asset not based on a national currency.

By researching the existing literature, Dorrucci \& McKay (2011) identified the following scenarios: a multipolar monetary system; a global monetary system with supranationality elements, in two versions - a monetary system based on SDR and a BANCOR-based system.

Benassy-Quere \& Pisani-Ferry (2011) have compared two systems: hegemony - a system in which one currency is used by all countries as an anchor, a reserve instrument and as a store of value; multipolarity - a system with several key currencies, having free capital mobility and floating exchange rates; these currencies can serve as an anchor and reserve instrument at regional level while periphery countries can choose to let their currencies float but with the ability to limit capital flows if they become excessively volatile. The comparative analysis is made by the criteria of efficiency, stability and equity. The authors believe that the current system is a combination of these two alternatives: it implies more floating than the hegemonic system, but it is less symmetrical than the multipolar regime.

Angeloni et al. (2011) underlined three possible scenarios: a repair-and-improve scenario; a multipolar system in which the US dollar is joined by other international currencies (euro, renminbi or other currencies); a multilateral monetary system in which parties convene on the steps to be taken to consolidate the international monetary order. The evaluation is also made using criteria such as efficiency, stability, equity and feasibility. The first scenario is seen as viable on short term, the second one is seen as viable during the next 10-15 years, while the third scenario is less likely to occur.

Lin, Fardoust, \& Rosenblatt (2012) perceived three scenarios: continuation of the current 'non-system', with a high volatility of capital flows and exchange rates; a multimonetary system with three reserve currencies - US dollar, euro and renminbi; the orientation toward a new supranational currency. Their study focuses on the multicurrency reserve system, as the most possible scenario on medium-term.

Analyzing the global monetary system, Ocampo (2015) proposed a global reserve system that mixes the multicurrency arrangement with a more active use of SDR.

Wang (2016) compared different monetary systems of major currencies (US dollar, euro, renminbi) and SDR-based and tried to identify the feasible way for the future international monetary system.

Farhi \& Maggiori (2018) proposed a simple model of the international monetary system, analyzing the reserve supply and demand denominated in different currencies under three scenarios: a hegemon versus a multipolar world; abundant versus scarce reserve assets; a gold exchange standard versus a floating rate system.

Taylor (2019) argues that a rules-based reform of the international monetary system, by applying basic economic theory, would improve economic performance and offers an agenda for reform.

During the COVID-19 pandemic, Murau, Rini, \& Haas (2020) explore the following four scenarios for the global financial system in 2040: a continuation of the current US 
dollar hegemony; the co-existence of competing monetary blocks; the emergence of an international monetary federation; or international monetary anarchy.

\section{Alternative models of the US dollar international monetary system}

The answers to our questions are disputable, but decisive to evaluate the opportunity of reforming the current international monetary system. Possible answers are given by the alternative models for configuring the international monetary system coming from the proposals of economists, international organizations or policy makers under the shape of different scenarios:
a) designing a new Bretton Woods system;
b) raising the monetary gold importance;
c) increasing the role of the SDR;
d) creating a global/supranational currency;
e) a multimonetary system.

\section{a) designing a new Bretton Woods system}

The Bretton Woods agreement have had a major contribution to ensuring the world development and stability, three decades after the World War I. Proposals for a new Bretton Woods system are since the 1980s. At the end of 2008, some European leaders suggested a returning to the Bretton Woods international monetary system: ECB President Jean Claude Trichet believed that we should comeback to Bretton Woods discipline; British Prime Minister Gordon Brown said that a rethinking of the financial architecture must be considered, with a discipline similar to Bretton Woods system; French President Nicolas Sarkozy and British Prime Minister Gordon Brown proposed a multilateral accord to stabilize international finances in the 21st century.

Existing literature presents different opinions, from voices which argue that the current system is in fact a revival of Bretton Woods - (Dooley, Folkerts-Landau \& Garber, 2003), (Eichengreen, 2004), (Dooley, Folkerts-Landau \& Garber, 2009), (Hall, Hondroyiannis, \& Tavlas, 2010) - to those who believe that a new Bretton Woods is required (Stiglitz, 2008) and (Boughton, 2009) or views which state that Bretton Woods is not an appropriate system for today (Schwartz, 2000) and (Goldstein, 2005).

It is certain that a new international monetary agreement could impose discipline. It should not be forgotten that in 1944 were established the rules which governed the global economy for the next 30 years. From this perspective, a returning to Bretton Woods, in an adapted format to today`s realities, would be preferred, but unlikely to come true.

\section{b) raising the monetary gold importance}

Robert Mundell (Mundell, 1997) has considered the gold as part of the structure of the 21 st century international monetary system, but not in the way it has been used in the past, in the gold standard period when there was a balance between world powers and no currency dominated.

On the other hand, the President of the World Bank, Robert Zoellick (Knight, 2010) didn't plead for a return to monetary gold, which he called 'the elephant in the room' and 
recommended that it can be considered by decision factors as an indicator for the exchange rates.

Many papers argue a more important role of the gold, without advocating a return to a gold standard system. The Royal Institute of International Affairs (Astrow, 2012) evaluated the advantages and disadvantages of reintroducing the use of the gold and concentrated on four directions in which gold could have an essential role for increasing the performance of the international monetary system: as a monetary anchor, as a hedge or safe heaven, as collateral and as an indicator of fiscal and monetary policy. As an alternative to the current system, they noticed the gold inclusion in the SDR basket and the possible role of 'digital gold'. The Official Monetary and Financial Institutions Forum (WGC, 2013) assumed that the role of gold will be further enhanced in the next 10 years because of the US dollar and the euro uncertainties, especially as an alternative reserve asset.

Gold is an important part of the international reserves, especially in developed countries. The global crisis has made central banks to become net buyers of gold again in 2010 for the first time since the 1980s (O'Connor, Lucey, Batten, \& Baur, 2015). According to data for June 2020 of the World Gold Council (WGC, 2020), United States ranks first (8133.5 tonnes, $79.1 \%$ of reserves), followed by Germany (3363.6 tonnes, $75.0 \%$ of reserves), Italy (2451.8 tonnes, $70.5 \%$ of reserves) and France ( 2436.0 tonnes, $65.0 \%$ of reserves). Emerging economies hold a small proportion of gold in their reserves, but they have significantly increased the size of their holdings in recent years: Russian Federation (2298.7 tonnes, $22.2 \%$ of reserves), India (653.0 tonnes, $7.4 \%$ of reserves) and China (1948.3 tonnes, $3.3 \%$ of reserves).

The gold price has increased by about 6 times during the last 20 years, from 279.1 US dollar per ounce in 2000 to 1527.10 in January 2020 and to 1748.30 US dollar per ounce in May 2020.

During times of crisis, it is known a demand for gold as a safe haven. But gold as an investment asset could appear in good times too. This situation is likely to continue, reflecting the current environment of high uncertainty, concerns on capital markets and historically low interest rates. We think that it proves once again the need for discipline and stability, but a return to gold standard in international monetary system seems more a myth rather than a practical solution.

\section{c) increasing the role of the SDR}

The SDR (Special Drawing Rights) basket is traditionally formed of most important currencies, the percentage of each being determined through economic and financial data of issuing countries: the value of goods and services export; the value of reserves denominated in that currency held by other IMF member states. The IMF reviews this basket every five years to ensure that the SDR reflects the relative importance of currencies in the world's trading and financial systems.

On January 1999, the German mark and the French franc were replaced by the equivalent amount of Euro, reflecting the economic power of Germany and France. Starting with January 2001, the new evaluation (29\% euro) was based on the importance of the Eurozone as a whole. During 2001-2011, there was a falling of the weight of the US 
dollar (to $41.9 \%$ in 2011) and the Japanese yen (to 9.4\%) and an increase of the euro weight (to $37.4 \%$ ) and the Pound sterling (to 11.3\%). In November 2015, the IMF decided that the Chinese renminbi met the criteria for inclusion in the SDR and therefore the renminbi joined in October 2016. The inclusion of the renminbi in the SDR has diversified the basket and made its composition more representative of the world's major currencies (41.73\% US dollar, $30.93 \%$ euro, $10.92 \%$ renminbi, $8.33 \%$ Japanese yen and $8.09 \%$ Pound sterling) (IMF, 2019).

Some articles regarding the reform of the international monetary system are focused on the increased role of the SDR as a reserve currency. The proposal of a substitution account revived in time of crisis: (IMF, 2010); (Kenen, 2010a); (Angeloni et al., 2011); (Farhi, Gourinchas, \& Rey, 2011); (Kenen, 2011); (McCauley \& Schenk, 2014). Transforming the SDR into a global reserve asset as an alternative to the US dollar was considered by Bergsten (2009), Kenen (2010b), Camdessus (2011) and Ocampo (2011, 2015). The Commission of Experts of the President of the General Assembly of the United Nations for the Reform of the International Financial and Monetary System (UN, 2009) suggested a gradual shift from the US dollar to SDR.

For increasing the SDR's attractiveness, the Official Monetary and Financial Institutions Forum (WGC, 2013) supported extending the SDR to include the R-currencies - Chinese renminbi, Indian rupee, Brazilian real, South African rand and Russian rouble with the addition of gold.

The International Monetary Fund (IMF, 2016) analyzed the role of the SDR on three levels, exploring whether a broader role could contribute to its smooth functioning: the official SDR, the composite reserve asset issued by the IMF; the SDR-denominated financial instruments, which could be both issued and held by any parties; and the SDR as a unit of account. The second level may be attractive to investors in a system with capital controls, such as China. Describing the SDR development, Harrison (2018) examined the potential for enhanced SDR to play a role in reducing the tensions and anomalies in the present international monetary system.

Since 1969 when it was created, the SDR served only as a unit of account. Now, the renminbi inclusion in the SDR could facilitate China's financial reform and could be considered an opportunity for the reform of the international monetary system - increasing the role of the SDR would be the least difficult path to it.

\section{d) creating a global/supranational currency}

The idea of a global currency is not new. It belongs to Keynes who refined it in his Bretton Woods proposal for an International Clearing Union in 1944.

Before the outbreak of the global crisis, Mundell (2005) has proposed a currency basket called DEY with specific weights for the US dollar, the euro and the yen or the yuan (renminbi), which would become the platform for creating a global currency, called INTOR, possibly linked with gold. He assumed that since the introduction of the euro, the United States is no longer the unquestioned 'dictator'. Two years later, Moshirian (2007) has explored the way a global single currency could emerge, by creating some international institutions such as a World Central Bank, a World Parliament and a World Government. 
In the post crisis discussions, most opinions are oriented towards creating a new currency basket as a global currency - a supranational international reserve currency. Zhou Xiaochuan, Governor of the People`s Bank of China (Zhou, 2009) has proposed the replacement of the US dollar with a global reserve currency, disconnected from individual nations and stable in the long run, as a basket of the most important currencies, eventually an extended SDR. The Commission of Experts of the President of the General Assembly of the United Nations for the Reform of the International Financial and Monetary System (UN, 2009) stated that a global reserve currency not linked to the external position of any national economy could provide a more stable system.

Costabile (2009) has distinguished between the 'key currency', a characteristic of the current asymmetrical system, as a national currency with international use and the 'supranational currency', for instance BANCOR in Keynes's system, issued by a supranational institution. In the same way, Yeh (2012) analyzed whether a multicurrency (G3 plus renminbi) cooperative mechanism can be sustained and concluded that it is hardly feasible, and a supranational policy institution is necessary according to the theory of endogenous optimum currency area.

In 2010, the International Monetary Fund (IMF, 2010) has supported the idea of a new global currency, called BANCOR and issued by a global central bank. Although it grants a higher importance to SDR, the Fund (IMF, 2011) does not see the SDR as the final solution, but rather a transition towards the new global currency.

The IMF is now the issuer of the only global currency - SDR - as a unit of account. Could the IMF take the responsibility for managing the global reserve system? Are the countries of the world ready to give up monetary sovereignty in favor of a Global Reserve Bank? These are the questions for which no answers have yet been found.

In our opinion, such a proposal is not realistic in times of crisis, but it could be considered for the future.

\section{e) a multimonetary system}

In the literature there are opinions about reconsidering the dominant position of the US dollar. The history has proven than empires do not last forever. If the US empire is declining, the question is whether we can find viable alternatives and which currency could replace the US dollar. There is no consensus concerning this currency and who could share the power with the United States.

On the one hand are those who support the US dollar. Kenen (2010a) argued that there is no plausible candidate which could replace the US dollar. Benassy-Quere \& Pisani-Ferry (2011) have proved in 2011 that the US dollar will remain the main international currency, although it will gradually lose its domination and in a decade or two it no longer be the system's only key currency. Using a 'four I's' approach to identify the main sources of negative externalities in the current international monetary system (instability, incertitude, inequity and insufficiency of the aggregate demand), Ponsot (2016) invalidated any supposition that we are witnessing the end of the US dollar-based system, at least in the short or medium term, considering that euro has only a secondary international role. 
Others see a shift towards a multimonetary system as a natural consequence of the United States` economic dominance decline, the Asia`s emergence as the world`s new economic power and the multipolar nature of the global economy, together with the internationalization of the renminbi: Eichengreen (2010); Angeloni et al. (2011); Bergsten (2011); Bini Smaghi (2011a); Bini Smaghi (2011b); Eichengreen (2011); Fratzscher \& Mehl (2011); Salvatore (2011); Park \& Wyplosz (2012); Eichengreen (2013); Chitu et al. (2014).

Eichengreen $(2010,2011)$ considered that the future belongs to a system with multiple reserve currencies, centered around the US dollar, the euro and the renminbi. In another paper (Eichengreen, 2013), he studied the impact of moving from a unipolar to a multipolar monetary system on exchange rate stability. Analyzing three scenarios for international monetary system configuration, Angeloni et al. (2011) indicated that the most probable scenario is multipolar. Bergsten (2011) notified that the United States should anticipate some changes and start to build a framework with several rival currencies for the US dollar. Bini Smaghi (2011a) mentioned that the emergence of a multipolar currency system would accompany the global rebalancing of economic power that is taking place, but this should ideally occur gradually. The author (Bini Smaghi, 2011b) believed that a truly multipolar monetary system implies better policy incentives for stability-oriented policies. Fratzscher \& Mehl (2011) showed that the renminbi has become a determining factor of currency movements in emerging Asia since 2000 and even more during the crisis. Their research continued in the European Central Bank study (ECB, 2012), where they analyze 'the Chinese dominance hypothesis' and the potential orientation towards a tripolar global monetary system. To answer the question of whether the current system is already tripolar (with the US dollar, the euro and the renminbi), they test this hypothesis and compare it to the 'German dominance hypothesis' which attributed to the Deutsche Mark a dominant role in Europe in the 1980s and 1990s. The empirical results are consistent with this hypothesis that the international monetary system is becoming tripolar. Salvatore (2011) underlined that the most serious shortcoming of the international monetary system is the large and persistent misalignments among the world's leading currencies (US dollar, euro and renminbi). Park \& Wyplosz (2012) have thought that the future international monetary system will be shaped by a three-polar system consisting of the US, China, and Eurozone. Chitu et al. (2014) found that that a shift from a unipolar US dollar-based system to a multipolar one could happen sooner than often believed, by analogy with the period when the US dollar overtook Pound sterling much earlier than commonly supposed. They suggested that other currencies would increase their international status by financial deepening.

Sceptics warn that a multicurrency international system would be a source of instability. Dailami \& Masson (2009) expected the decrease of the US dollar's domination to be a gradual process, arguing that a multipolar monetary environment may exacerbate monetary instability, which calls for measures to prevent financial volatility through cooperation on monetary policies, intervention on the exchange market and financial regulation. More recently, Mitsuhiro Furusawa, the IMF Deputy Managing Director (Furusawa, 2017) remarked that a multicurrency system alone will not solve the shortcomings of the international monetary system, on the contrary it could increase systemic risks. 
At the same time, there are many views regarding the moment of functioning a multipolar monetary system, from those who claim this will occur on a short or medium term, as a result of the development of emerging markets and China power (Eichengreen, 2010; Fratzscher \& Mehl, 2011), to those who believe this will happen on long term (Angeloni et al., 2011; Benassy-Quere \& Pisani-Ferry, 2011; Frankel, 2011; Kenen, 2011; Lin et al., 2012).

\section{Conclusions}

Each of the alternative models for configuring the international monetary system have pros and cons. Some of them are unlikely to become true. Each system has its winners and losers.

The SDR-based system is not universally accepted, that makes us believe it is not a viable solution, particularly because since its beginning, the SDR remained a unit of account and never really became attractive.

The system based on a global/supranational currency is not a realistic scenario, but we do not completely dismiss the idea. The EU and Eurozone evolutions (considerable public debt and budgetary deficits, lack of a common vision, Brexit) show the difficulties which can occur within a supranational currency system. Such a system implies the fulfilment of all conditions for a monetary union, that did not happen in the Eurozone. Moreover, a global currency should associate with a supranational entity to issue and regulate it.

The multimonetary system - with a free movement of capital and a flexibility of the exchange rate - has the main advantage of stability, due to the macroeconomic policy discipline of the issuing countries, imposed by the competition between these currencies. The drawback could be the short-term increase of capital flows and exchange rate volatility, because of economic differences between the countries that issue the reserve currencies. This volatility could be avoided or even reduced if the transition towards a multipolar system will be gradually, by coordinating the efforts of all factors involved (central banks, governments etc.) and through international cooperation.

Because the world economy becomes more multipolar, we assume the foreseeable evolution is towards a multicurrency system - with the US dollar, the euro and the renminbi as main currencies. For a few years, the US dollar confidence eroded, and other international currencies are used by central banks in their reserves that pointing to the emergence of a multicurrency reserve system.

For certain, the shape of the international monetary system for the next years will be significantly influenced by the views, interests, changes and adjustments of the emerging powers, especially China. The China's policy goal of renminbi internationalization suggests a period of transition to a new monetary order. How smooth or rough it will happen remains to be seen.

And if the global crisis has induced the growth of the China role in the international monetary governance and the increase of the renminbi internationalization, the COVID-19 pandemic and post crisis reconstruction could generate a deeper reform of the 
international monetary system, in which the Chinese currency will strengthen its global position alongside the US dollar and the euro.

While the measures taken since 2008 indicate a movement toward correcting some of the international monetary system deficiencies (ex. capital and liquidity buffers as a result of the higher regulatory requirements), there are still many problems and new economic and financial challenges have arisen in the global economy post COVID-19. In this context, a new synthetic approach could be a good start for future research.

\section{References}

Angeloni, I., Benassy-Quere, A., Carton, B., Darvas, Z., Destais, C., Pisani-Ferry, J., . . Vallee, S. (2011). Global Currencies for Tomorrow: A European perspective. Retrieved from https://ec.europa.eu/economy finance/publications/economic paper/2011/pdf/ecp444 en.pdf

Astrow, A. (Ed.) (2012). Gold and the International Monetary System. A Report by the Chatham House Gold Taskforce. London: Royal Institute of International Affairs.

Benassy-Quere, A., \& Pisani-Ferry, J. (2011). What International Monetary System for a FastChanging World Economy? In J. T. Boorman \& A. Icard (Eds.), Reform of the International Monetary System: The Palais Royal Initiative (pp. 255-298): Emerging Markets Forum.

Bergsten, C. F. (2009). The Dollar and the Deficits: How Washington Can Prevent the Next Crisis. Foreign Affairs, 88(6).

Bergsten, C. F. (2011). Why the World Needs Three Global Currencies. Financial Times.

Bini Smaghi, L. (2011a). The reform of the international monetary system. Retrieved from https://www.ecb.europa.eu/press/key/date/2011/html/sp111216.en.html

Bini Smaghi, L. (2011b). The Triffin dilemma revised. Retrieved from https://www.bis.org/review/r111005a.pdf

Boughton, J. (2009). A New Bretton Woods? Finance \& Development, 46(1).

Camdessus, M. (2011). Toward a New International Monetary System. In J. T. Boorman \& A. Icard (Eds.), Reform of the International Monetary System: The Palais Royal Initiative (pp. 33-44): Emerging Markets Forum.

Chitu, L., Eichengreen, B., \& Mehl, A. (2014). When did the Dollar Overtake Serling as the Leading International Currency? Evidence from bond markets. Journal of Development Economics, $111,225-245$.

Costabile, L. (2009). Current Global Imbalances and the Keynes Plan. A Keynesian Approach for Reforming the International Monetary System. Structural Change and Economic Dynamics, 20, 79-89.

Dailami, M., \& Masson, P. (2009). The New Multi-polar International Monetary System. World Bank Policy Research, 5147.

Dooley, M., Folkerts-Landau, D., \& Garber, P. (2003). An Essay on the Revived Bretton Woods System. NBER Working Paper, 9971. Retrieved from https://www.nber.org/system/files/working papers/w9971/w9971.pdf

Dooley, M., Folkerts-Landau, D., \& Garber, P. (2009). Bretton Woods II Still Defines the International Monetary System. NBER Working Paper, 14731. Retrieved from https://www.nber.org/system/files/working papers/w14731/w14731.pdf

Dorrucci, E., \& McKay, J. (2011). The International Monetary System After the Financial Crisis. ECB Occasional Paper Series, 123.

D'Arista, J. (2009). The Evolving International Monetary System. Cambridge Journal of Economics, 33, 633-652. 
ECB. (2012). The International Role of the Euro. Retrieved from https://www.ecb.europa.eu/pub/pdf/ire/euro-international-role201207en.pdf

Eichengreen, B. (2004). Global Imbalances and the Lessons of Bretton Woods. Cambridge: MIT Press.

Eichengreen, B. (2010). Managing a Multiple Reserve Currency World. Insights, 29-33.

Eichengreen, B. (2011). The Renminbi as an International Currency. Journal of Policy Modeling(33), 723-730.

Eichengreen, B. (2013). Number One Country, Number One Currency. The World Economy, 36(4).

Farhi, E., Gourinchas, P. O., \& Rey, H. (2011). Reforming the International Monetary System. Retrieved

from http://www.cepr.org/pubs/books/cepr/Reforming the International Monetary System.pdf

Farhi, E., \& Maggiori, M. (2018). A Model of the International Monetary System. Quarterly Journal of Economics, 133(1), 295-355.

Frankel, J. (2011). Historical Precedents for Internationalization of the RMB. Council on Foreign Relations Working Paper.

Fratzscher, M., \& Mehl, A. (2011). China`s Dominance Hypothesis and the Emergence of a Tri-Polar Global Currency System. ECB Working Paper Series, 1392.

Furusawa, M. (2017). Strengthening the International Monetary System. Paper presented at the Conference on the Future of International Monetary System for Asia, Tokyo. https://www.imf.org/en/News/Articles/2017/03/08/SP030817-Strengthening-the-InternationalMonetary-System

Goldstein, M., Lardy, N. (2005). China`s Role in the Revived Bretton Woods System: A Case of Mistaken Identity. Institute for International Economics Working Paper, 2.

Hall, S., Hondroyiannis, G., \& Tavlas, G. (2010). Bretton-Woods Systems, Old and New, and the Rotation of Exchange-Rate Regimes. Bank of Greece Working Paper, 112.

Harrison, M., Xiao, G. (2018). Enhanced Special Drawing Rights: How China Could Contribute to a Reformed International Monetary Architecture. China \& World Economy, 26(4).

IMF. (2009). The Debate on the International Monetary System. IMF Staff Position Note, SPN/09/26.

IMF. (2010). Reserve Accumulation and International Monetary Stability. Retrieved from https://www.imf.org/external/np/pp/eng/2010/041310.pdf

IMF. (2011). Enhancing International Monetary Stability - A Role for the SDR? Washington: IMF

IMF. (2016). Staff Note for the G20: The Role of the SDR-Initial Considerations.

IMF. (2019). Special Drawing Rlghts (SDR). Retrieved from https://www.imf.org/en/About/Factsheets/Sheets/2016/08/01/14/51/Special-Drawing-RightSDR

Kenen, P. (2010a). Reforming the Global Reserve Regime: The Role of a Substitution Account. International Finance, 13(1), 1-23.

Kenen, P. (2010b). Renovation of the Global Reserve Regime: Concepts and Proposals. CEPS Working Paper, 208.

Kenen, P. (2011). Beyond the Dollar. Journal of Policy Modeling, 33, 750-758.

Knight, R. (2010). Zoellick Sees 'Elephant,' Not Endorsing Gold Standard. Retrieved from https://www.cnbc.com/id/40104492

Lin, J. Y., Fardoust, S., \& Rosenblatt, D. (2012). Reform of the International Monetary System. A Jagged History and Uncertain Prospects. World Bank Policy Research Working Paper, 6070.

McCauley, R. N., \& Schenk, C. R. (2014). Reforming the International Monetary System in the 1970s and 2000s: Would an SDR Substitution Account Have Worked? BIS Working Papers, 444.

Moshirian, F. (2007). Global financial services and a global single currency. Journal of Banking \& Finance, 31, 3-9. 
Mundell, R. (1997). The International Monetary System in the 21st Century: Could Gold Make a Comeback? Lecture delivered at St. Vincent College, Letrobe, Pennsylvania, March 12, 1997. Mundell, R. (2005). The Case for a World Currency. Journal of Policy Modeling, 27, 465-475.

Murau, S., Rini, J., \& Haas, A. (2020). The Future of Offshore Dollar Creation: Four Scenarios for the International Monetary. IASS Discussion Paper. Retrieved from https://publications.iasspotsdam.de/rest/items/item 3259916 4/component/file 3259927/content

O'Connor, F. A., Lucey, B. M., Batten, J. A., \& Baur, D. G. (2015). The financial economics of gold A survey. International Review of Financial Analysis, 41, 186-205.

Ocampo, J. A. (2011). Reforming the International Monetary System. WIDER Annual Lecture 14. Retrieved from https://www.wider.unu.edu/publication/reforming-international-monetarysystem

Ocampo, J. A. (2015). Reforming the Global Monetary Non-system. WIDER Working Paper 146. Retrieved from https://www.wider.unu.edu/sites/default/files/wp2015-146.pdf

Park, C. Y., \& Wyplosz, C. (2012). International Monetary Reform: A Critical Appraisal of Some Proposals. ADBI Working Paper Series, 364.

Ponsot, J. F. (2016). The "four I's" of the International Monetary System and the International Role of the Euro. Research in International Business and Finance, 37, 299-308.

Salvatore, D. (2011). The Future Tri-polar International Monetary System. Journal of Policy Modeling, 33, 776-785.

Schwartz, A. (2000). Do We Need a New Bretton Woods? Cato Journal, 20(1).

Stiglitz, J. (2008). The Next Bretton Woods. Retrieved from http://www.projectsyndicate.org/commentary/the-next-bretton-woods

Subacchi, P., \& Driffill, J. (Eds.). (2010). Beyond the Dollar. Rethinking the International Monetary System. A Chatham House Report. London: Royal Institute of International Affairs.

Taylor, J. B. (2019). Reform of the International Monetary System. Cambridge: MIT Press.

UN. (2009). Report of the Commission of Experts of the President of the United Nations General Assembly on Reforms of the International Monetary and Financial System. Retrieved from https://digitallibrary.un.org/record/657634?!n=en

Wang, J. (2016). The Past and Future of International Monetary System. In Springer (Ed.), The Past and Future of International Monetary System. Singapore: Springer.

WB. (2011). Global Development Horizons 2011: Multipolarity - The New Global Economy. Retrieved from https://openknowledge.worldbank.org/handle/10986/2313

WEF. (2012). Euro, Dollar, Yuan Uncertainties Scenarios on the Future of the International Monetary System. Retrieved from Geneva: http://reports.weforum.org/euro-dollar-yuan-uncertaintiesreport-2012/

WGC. (2013). Gold, the Renminbi and the multi-currency reserve system. Retrieved from https://www.gold.org/goldhub/research/gold-renminbi-and-multi-currency-reserve-system

WGC. (2020). World Official Gold Holdings. Retrieved from https://www.gold.org/goldhub/data/monthly-central-bank-statistics

Yeh, K. C. (2012). Renminbi in the future international monetary system. International Review of Economics and Finance, 21(1), 106-114.

Zhou, X. (2009). Reform the International Monetary System BIS Review, 41. 